\title{
WOMEN ON BOARDS OF PHILIPPINE CORPORATIONS: QUANTITATIVE EXPLORATIONS
}

\author{
Maria Cristina G. Bautista* \\ Ateneo de Manila University, Makati City, Philippines \\ Marlene M. De Leon \\ Ateneo de Manila University, Quezon City, Philippines \\ Rudyard Jose R. Nano IV \\ Ateneo de Manila University, Makati City, Philippines
}

\begin{abstract}
This inductive study explored the likelihood and correlates of gender diversity in corporate boards in the Philippines. The improvement of gender diversity on boards is of advocacy and policy interest as the country emerges to middle-high income status. Logistic regression analyses from individuals' (in a directors' talent pool) responses to an online survey showed that females had a likely odds of 0.10 to be on the boards, compared to males. For every one female getting onto boards, 9 would be unable to. Females with advanced degrees were $7 \mathrm{x}$ likely to be on boards than female and male counterparts. The odds of a board seat is significantly likely for individuals in some industries compared to a referent industry (government). At the firm level, controlling other variables in the model, as the size of boards are increased by a unit, the odds of having a woman on board increase 1.3 times. This implies that the likelihood of having a woman board of director rises if the size of boards is raised by a third. Corroboration from text mining technique applied to survey responses showed strong correlation across academic degrees (both bachelor's and advanced), industry, and job title; pointing that having more women in C-roles increase the odds of increasing their numbers on corporate boards. Gender diversity on boards have been studied largely from the developed economy lens and/or international comparisons. These quantitative explorations showed pathways that can advance not only understanding and support for extant theories (human capital, resource dependence), but also point to further work (institutional, industry) that can provide levers for policy and advocacy, for countries with similar challenges.
\end{abstract}

Keywords: Gender diversity; Philippines; corporate boards; Logistic regression; Machine learning

- Corresponding author: Dr. MC G Bautista, Professor, Graduate School of Business, Ateneo de Manila University, 2F, Ateneo Professional Schools Building, 20 Rockwell Drive, Rockwell Center, Makati City 1200 Philippines, Tel.632-8899946, mcbautista@ateneo.edu. 


\section{INTRODUCTION}

Weak female participation in corporate boards has led several countries - especially in Europe, to mandate a female board membership quota. Although the Philippines has no specific government mandate for women on boards, a recommendation from the Philippine Securities Exchange Commission (SEC) was released in 2015, encouraging the election of at least one female independent director (aligned with the ASEAN corporate governance scorecard) (Unite, Sullivan, \& Shi, 2016a). Despite these efforts to even out the male-female ratio in the boardroom, progress in attaining the goal has been slow. Based on the 2016 report by Deloitte Global Center for Corporate Governance, the percentage of board seats held by women globally are only at $15 \%$; a three percent point rise from 2014. Remarkably, developing countries are found to lead corporate diversity (Mckinsey Global Institute, 2018). Our study's data showed that only 15.5 percent of corporate board members are women ${ }^{1}$.

In the Asia Pacific region, female board membership is $7.8 \%$, with ASEAN countries reporting a higher incidence of women in senior roles (34\%) compared to the global average (24\%) (Grant, 2016). The Philippines topped the region with $39 \%$ of females in senior management roles and ranked 10th, which is a decline from 7th place in earlier years, among countries that led in the Gender Gap index (World Economic Forum, 2017). Despite ranking high in gender status in the region, a question still remains on the relatively small representation of women in Philippine boardrooms. This present study addresses the research question: What are the drivers for women to be on the boards of Philippine corporations? This research specifically aimed to address the following objectives: firstly, determine the likelihood an individual will be in a corporate board; secondly, explore the determinants of having or not having a woman on the boards; and lastly, examine for corroborating variables on patterns detected from text mining technique.

This study is significant with its primary-sourced data coming from individuals in a talent pool of potential and existing board of directors. The exploration involved quantitative techniques including machine learning and individual and firm level logistic regression analyses to provide directions for policy and advocacy work. The findings drawn from this inductive process can be used to generate hypotheses applying extant theories on increasing women representation in company boards.

\section{LITERATURE REVIEW}

A considerable body of literature including reviews has grown around diversity in corporate governance - in general and in particular-around what gender diversity brings to firm performance (Cabrera-Fernández, Martínez-Jiménez, \& Hernández-Ortiz, 2016; Grosvold, 2011; Terjesen, Sealy \& Singh, 2009; Wagana \& Nzulwa, 2016). Perhaps indicative of the maturity of the field, a 2009 review by Terjesen et al. included 400 publications, though only one in ten of the papers covered theoretical developments. The authors categorized theoretical advances as multilevel: a) at the level of individual - human and social capital theories; b) at board level - social identity, tokenism and social networks, c) at the firm level-resource dependency, institution and agency theories; and d) environmental level - institutional, critical and political theories. The

${ }^{1} 2017$ corporate dataset from the Philippine Stock Exchange (PSE) collated through this research. 
reviews gave a brief description of these concepts and theories, with resource dependency theories (RDT) having been used more widely for understanding boards, though not as widely applied as compared to agency theory (Hillman, Withers, \& Collins, 2009). Agency theory looked at firm performance being influenced by the boards, and by extension, how gender representation on boards are factors explaining firm performance by various measures. Hillman, Shropshire and Cannella, Jr. (2007) noted that while diversity has been explored in terms of age, functional background and tenure, gender has not been a focus. Gender was examined largely at work group level and not at the board level.

Cabrera-Fernández et al. (2016) examined 76 studies that looked at women's contribution to firm profitability, establishing the 'business case' for having more women on boards. Research reported the linkage as mixed (Kolev, Hughes-Morgan, \& Rehbein, 2019; Wagana \& Nzulwa, 2016). Kang and Payal (2012) reviewed several studies which indicated positive effects of having women on boards, while other studies also showed negative findings (Abdullah, Ismail, \& Nachum, 2016; Ahern \& Dittmar, 2012). A study by Adams and Ferriera (2009), one of the principal proponents of the agency perspective, looked into the impact of women in the boardroom to governance and firm performance. Their findings showed that gender diverse boards positively affect board inputs in terms of director attendance and committee assignment. Female directors were viewed as tougher monitors than male directors, which can substantially influence turnover-performance sensitivity.

Hillman et al. (2009) marked that it has been 30 years since the seminal work of Pfeffer and Salancik (1978) on resource dependence theory appeared. Early empirical work identified board size and composition as one of the early indicators of the boards' ability to provide resources to the firm (Pfeffer, 1972 as cited in Hillman et al., 2009). Under RDT, board of directors were viewed to bring four salient benefits to organizations: a) advice and counsel; b) channels of information; c) preferential access to resources and d) legitimacy.

A Philippine study by Unite, et al. (2016a), using time series (2003-2014) data of publicly listed firms, found that having women on boards did not significantly affect financials (measured by Returns on Equity and Returns on Assets) in the short term; and may have driven long term firm value (measured by Tobin Q) down. Robustness checks were made for potential endogeneity of gender diversity as well as unobserved individual effects. The authors point to the investor bias theory as a possible explanation, that is, the biased perception of women as incapable may hold down the market value of firms where women hold directorship or leadership roles. This perception or its source was not sufficiently explained in the paper which relied on secondary data. The same authors' (Unite, Sullivan, \& Shi, 2016b) descriptive study of women in leadership positions of 250 publicly listed firms across five year intervals, showed gender gaps, yet gradual improvements in female leadership roles in firms. Educational backgrounds of firm CEOs (chief executive officers) appear to be similar in terms of undergraduate and graduate degrees and schools they obtained them from.

Further examination of female CEOs may have moderated board directions. Galbreath (2018) noted that with the tenuous relationship between women and board representation with the firm profitability, an indirect relationship may be found through the mediating factor of corporate social responsibility (CSR), following stakeholder theory. Women were viewed to be more attuned to pro-social actions, leading to higher CSR, which is linked to financial performance. Recent articles 
in this journal also explored the women directors and financial performance linkages. Women board of directors influenced positively the complexity and volume of competitive moves (Kolev et al., 2019), though negatively on the heterogeneity of competitive actions.

Fairly recent literature analysed how institutions of family, education, economy, government, and religion can influence the rise of women to corporate boards. From an international comparison of 23 countries using firm level data and national statistics through time series, random fixed effects model, (Grosvold, Rayton, \& Brammer, 2016) found strong significant positive influence of education (tertiary education for women) and government spending on day care. The authors found weak though significant effects of family (measured by divorce rates). Religion did not surface as a predictor of women's rates of board participation. An earlier reflexive article by one of their authors (Grosvold, 2011) provided an extensive literature review, in writing her dissertation, of the institutional dynamics influencing the prevalence of women on boards, from national, culturalcognitive, regulatory lenses. It paid particular insights into studying the board's nomination committee and how placing women in the committee can augur well for more women getting into boards.

Cabrera-Fernández et al. (2016) referred to a group of studies which they designated as 'empirical', applying inductive logic and developing arguments from the use of methodologies - qualitative and quantitative - and from the use of solid data. They identified 24 articles in this stream, looking into women on boards and firm's performance. Our present study is within the inductive stream of research in understanding the factors that can explain firstly, the likelihood of a board seat for an individual already in a pool of candidates, and secondly, the likelihood for companies to have at least one woman on their boards. From its unique context of access to individuals who are in a current directors talent pool - people who display (at least overtly) similar academic backgrounds and experience. The research was part of a limited duration consultancy on the prevalence of women on corporate boards in the country through exploration of available data sets and a rapid assessment or survey of members' views on increasing the number of women on boards. Another part of the research (not reported here) was a qualitative study which involved in-depth interviews of a few corporate directors for an ethnographic investigation (Bulaong Jr. \& del Rosario-Rondilla, 2018). Cross-disciplinal collaboration involving philosophy, anthropology, economics, law and business administration drew up the terms of reference and questionnaire.

\section{METHODOLOGY}

\subsection{Sample}

Two main data sources were utilised for the study: (1) An online survey, using Google forms, with 98 respondents answering a questionnaire exploring board membership, backgrounds, and perceptions on current and potential board membership for women; and (2) Secondary data from 248 companies $^{2}$ with 2016 information filed with the Philippine Stock Exchange and/or the Securities and Exchange Commission (SEC). A small pilot pre-tested the questionnaire, and revised for length and appropriateness of questions. The Google form survey reached the

\footnotetext{
${ }^{2}$ There were a total of 252 PLCs for 2016 in the databases and analysis was made on 248 of these companies, which had more complete information on the variables used
} 
respondents through an email blast to members of the group of corporate directors who were also requested to encourage their networks to participate. Statistical analysis was made on IBM SPSS v.20 (for Windows). Text mining analysis was applied to some questions on the Google forms responses to capture significant correlations.

\subsection{Levels of Analysis: Dependent Variables Used}

The research objective was through two main levels of analyses. The first level of analyses examined for the sources of differences in likely board selection. The source of the primary information or the respondents being from a talent pool of individuals similarly positioned to be board seat holders, we looked to model the characteristics that get them selected. The dependent or outcome variable was coded 1 if the individual in the sample were in a board and 0 if the individual were not. In the sample, $76(78 \%)$ were on the boards and $22(22 \%)$ were not on the boards.

The second level of analyses used firm level information to determine whether a company will have a woman board of director; and used firm level data to determine the presence of a woman on the companies' boards. The dependent or outcome variable was coded 1 if the firm had at least one woman board of director and 0 if there were no woman on the company's boards. In the sample, there were 248 companies and $159(64 \%)$ had at least one woman on their board of directors, while 89 (36\%) did not have women.

A third level of analyses used text mining component analysis as further exploratory device for robustness to determine whether the factors identified in the logistic regression will also surface and corroborate the pattern or the differences among factors observed.

\subsection{Analyses}

A multivariate logistic regression (LR) model was utilized, due to some peculiarities of data and focus, in particular: a) the use of nominal or dichotomous variables to determine likelihood as dependent variables; b) in anticipation of small sample size, with the absence of sampling frame and with prevalence estimates being part of the study results; and c) for flexibility as it permits no a priori assumption on the shape of distribution of the variables. For the latter, without the normal distribution assumption, no strict ordering or unequal variances are assumed (Meyers, Gamst, \& Guarino, 2016; Pett, 2016). This permits bypassing tests of validity for normal distribution assumptions.

LR provides information on how likely or unlikely it is for the selection (outcome) to occur, controlling for factors or conditions occurring in the samples. As a non-parametric technique, it does not make assumptions on the distribution of the outcome variable (Osborne, 2015 as cited in Pett, 2016).

The analysis results of logistic regressions are stated in terms of the odds ratio, or $\operatorname{Ex}(\mathrm{B})$ in SPSS software. It informs how likely or unlikely an outcome to occur given certain circumstances. It represents the change in odds of the outcome (e.g. board selection), given a one unit increase in the independent variable (e.g. categorical predictor like being male or female), controlling for other variables in the model. $95 \%$ confidence interval designates the true population odds ratio for a 
successful outcome, given that the dependent variable compared to its reference group is within the range shown. Odds ratio is a ratio of odds occurring for the target and referent group considered. It can take on a range from 0 to any high value, with higher chances for occurrence shown as more than 1, in the group coded 1; and less likely for the same group if the odds ratio is less than 1. Odds equal to 1 , with the event equally likely for the variable group, is equivalent to the null hypothesis in logistic regression.

There are two basic questions answered by logistic regression: a) how well does the model fit the data, and b) how well do the independent variables predict the outcome. The evaluation for model fit uses model chi-square value $(\chi 2)$ to test for a null hypothesis that coefficients entered are zero. When the set of independent variables significantly predict the outcome, the null is rejected. For the full model, a significant $\chi 2$ would lead to the conclusion that the model is a better predictor of the outcome variable than the null model.

Hosmer and Lemeshow Test is used as a formal test, matching predicted probabilities with the observed probabilities. A $p$ value which is nonsignificant is the desired outcome, indicating there is no significant difference between observed and predicted probabilities. The Hosmer and Lemeshow test is drawn from a contingency table that divides the sample into equal groups of 10 based on outcome variable. Observed and expected frequencies (of the prediction model) are looked at for match. LR also yields a classification table to show how well the model classifies cases into two categories of the outcome variable.

SPSS also tests for model fit through: 2-Likelihood Ratio, Cox and Snell pseudo R2 and Nagelkerke pseudo R2, or whichever is higher. Since the outcome variable is nominal, this R2 is not a true approximation (hence the designation of pseudo) of the explained variance in the dependent variables. The suggested interpretation is to consider these R2 values to be estimates of strengths - from low, to weak, moderate and strong effect sizes. Values range between 0 and 1.0, the closer to 1.0 would be considered strongest and closer to 0 as weak (Pett, 2016).

\subsection{Entry of Variables}

The software allowed for different ways to enter predictor variables for analysis and iterates accordingly to find the significant variables. In this article, two ways were explored-direct entry and backward stepwise entry. The first estimates, shown as the original model or model 0 , were a direct entry or under Enter in SPSS, where all predictor variables were simultaneously entered. Succeeding estimates were drawn using stepwise backward entry of data, where all the predictor variables were first entered and the nonsignificant ones were removed (by the software program) based on their statistical significance; with only significant predictors left in the final modelsolution. The target or the variable of interest is the focus. Female is designated as the variable of interest and coded 1. Referent or reference variables are the basis of comparison, since odd ratios are only meaningful in terms of another. 


\section{RESULTS}

\subsection{What is the likelihood of securing a board membership (s) from among similarly situated individuals in a directors' talent pool?}

The model looked into the likely success of a board seat (with the reference category of having a board seat $=1$ ) in terms of sex, age, having an advanced degree, type of industry and an interaction term between sex and advanced degree as predictor variables. Table 1 presents the descriptions and coding of the variables used, and their count or frequency in the sample. Over-all, there was a $2: 3$ ratio of females to males in our sample, with 56.7 years as average age, 70 percent held advanced degrees, and fairly well distributed across industry sectors, except for lower percentages in IT/logistics/distribution and in government/non-profit sectors.

Table 1:Variables Used and Measures

\begin{tabular}{|c|c|c|c|}
\hline Variable & Description & בCodes & $\begin{array}{c}\text { Count } \\
\mathrm{N}=98(\%)\end{array}$ \\
\hline Sex & Biological sex of respondent & $\begin{array}{l}1=\text { Females }^{\mathrm{a}} \\
0=\text { Males }\end{array}$ & $\begin{array}{l}40(41 \%) \\
58(59 \%)\end{array}$ \\
\hline Age group & $\begin{array}{l}\text { Indicates age group of } \\
\text { respondents by } 20 \text {-year } \\
\text { intervals }\end{array}$ & $\begin{array}{l}1=61 \text { and above } \\
2=41-60 \\
3=40 \text { and below }\end{array}$ & $\begin{array}{l}33(34 \%) \\
53(54 \%) \\
12(12 \%) \\
\end{array}$ \\
\hline Advanced degrees & $\begin{array}{l}\text { Refers to acquired degrees } \\
\text { beyond Bachelors' Includes } \\
\text { law, master's, medicine, etc. }\end{array}$ & $\begin{array}{l}1=\text { Has advanced degrees }^{\mathrm{a}} \\
0=\text { Does not have advanced } \\
\text { degrees }\end{array}$ & $\begin{array}{l}69(70 \%) \\
29(30 \%)\end{array}$ \\
\hline Industry & $\begin{array}{l}\text { Industrial sectors as identified } \\
\text { by respondents. Classified } \\
\text { into } 5 \text { categories }\end{array}$ & $\begin{array}{l}\text { 1= Industrial, Manufacturing, } \\
\text { Energy or Power } \\
\text { 2= Financial } \\
3=\text { Multi-services } \\
\text { 4= IT, Logistics, or Distribution } \\
\text { 5= Government or Non-profit }{ }^{\mathrm{a}}\end{array}$ & $\begin{array}{l}21(21 \%) \\
27(28 \%) \\
26(27 \%) \\
13(13 \%) \\
11(11 \%)\end{array}$ \\
\hline $\begin{array}{l}\text { Interaction term (Sex } \\
\text { by advanced degree) }\end{array}$ & $\begin{array}{l}\text { This variable involves the } \\
\text { interaction of sex (male, } \\
\text { females) with advanced } \\
\text { degrees }\end{array}$ & $\begin{array}{l}\text { Females with advanced degrees } \\
(\text { a.d.) } \\
\text { Females without a.d } \\
\text { Males with a.d } \\
\text { Males without a.d }\end{array}$ & $\begin{array}{l}27(28 \%) \\
13(13 \%) \\
42(43 \%) \\
16(16 \%)\end{array}$ \\
\hline
\end{tabular}

${ }^{\mathrm{a}}$ Reference category

Table 2 shows the results of a standard logistic regression to model the binary variable of board seat selection - whether one gets selected to the board $(=1)$ or not $(=0)$. Based on a classification threshold predicted probability of board seat selection as 0.5 , the results of the analysis indicated that the multivariate model provided a statistically significant prediction of success with the final model statistic, chi-square value $(\chi 2=17.28)$, significant at $0.008, p<0.05$. The final model had good fit to the data, with Hosmer-Lemeshow $\chi 2=2.07, \mathrm{p}>0.05$, showing that observed and predicted values matched. The Nagelkerke psuedo R2 indicated the final model accounted for approximately $25 \%$ of variance, considered a moderate influence. In the final model, females are 
a tenth as likely, compared to males, to get a position on the boards, with the odds ratio for board success at 0.10 , and highly significant $(\mathrm{p}=0.002)$.

Table 2: Odds Ratio Results from Logistic Regression Using Primary or Online Survey Data

\begin{tabular}{l|lll}
\hline \hline Predictor variables & Model 1 & Model 2 & Model 3 \\
\hline & OR (95\%CI) & OR (95\%CI) & OR (95\%CI) \\
\hline Age group & & & \\
$\quad$ 61 and above & $1.22(.2-8.2)$ & & \\
$\quad$ 41-60 & $0.80(0.1-4.9)$ & & $0.1(.0-.4)^{* *}$ \\
Sex_F1 & $0.03(0.0-0.4)^{* *}$ & $0.03(0.0-0.4)^{* *}$ & \\
Industry & & & $26.90(2.8-262.4)^{* *}$ \\
$\quad$ Energy/Power/Mftg & $23.54(2.3-240.3)^{* *}$ & $25.64(2.5-259.6)^{* *}$ & $4.66(0.9-23.7)$ \\
Financial & $4.44(0.9-23.2)$ & $4.66(0.9-24.1)$ & $12.63(1.9-84.7)^{* *}$ \\
Multi-services & $12.17(1.7-84.1)^{*}$ & $12.63(1.9-85.8)^{* *}$ & $3.14(0.5-19.9)$ \\
IT/Logistics/Distribution & $2.86(0.4-20.6)$ & $3.22(0.5-20.7)$ & \\
Advanced degree & $0.34(0.0-3.4)$ & $0.35(0.0-3.4)$ & $7.00(1.3-39.0)^{*}$ \\
Interaction term & $22.54(1.3-405.3)^{*}$ & $19.75(1.1-339.4)^{*}$ & \\
(Sex*Advanced degree) & & & $17.28^{* *}$ \\
\hline Model Fit Statistics & $18.68^{*}$ & 3.98 & 2.07 \\
Chi-square & 5.09 & 0.26 & 0.25 \\
Hosmer-Lemeshow & 0.27 & & \\
Nagelkerke & & & \\
\hline \hline
\end{tabular}

Note: The dependent variable was likelihood of having a board seat with 1 or more as the target category and No

Board seat $(=0)$ as reference category

$* \mathrm{p}<0.05$

$* * \mathrm{p}<0.001$

Source of data: online survey of respondents from a directors' talent pool members/network

Being female had the odds ratio of selection to the boards of 0.10 , compared to their male counterparts, holding other variables constant. Aside from sex, individual attributes like age, advanced degrees did not figure significant explanations for board selection, per se. When interaction effects were examined, the sex-advanced degree surfaced statistically significant and improved the model. Holding other factors constant, being female still mattered but interacting with advanced degree. The odds for a female with advanced degree to successfully secure a board position is $7 \mathrm{x}$ likely compared to females without advanced degrees and all males.

Two industry sectors, Energy/Power/Manufacturing and Multi-Services, came out as consistently significant throughout, controlling for other variables in the models. Industry-type is a variable assessed categorically compared to another industry sector (in this case, government and nonprofits). The sectoral distribution of industry are as follows: power/energy/industry/manufacturing, financial services, multi-services including property, IT sectors/logistics/distribution, and government/non-profit sector (as referent). The odds ratio for selection to board seats for women in power/energy/industry/manufacturing is $26.9(\mathrm{p}=0.005)$ and 12 in multi-services sector $(\mathrm{p}=0.009)$, compared to securing government seats. Wide confidence intervals were however observed for industries. On the face of it, controlling for other factors in the model, for individuals 
in traditional (manufacturing, energy, power) companies, the likelihood of having a woman on boards is $27 x$ than those in government. Similarly, holding for other factors, women in multiservices were $12 x$ likely (than government) to secure board seats.

The classification success for the cases based on a cut off value of 0.5 for predicting success in securing board seat was relatively high, with overall accuracy of the predictive model was 80.6 percent, predicting $98.7 \%$ of those with board seats correctly and $14 \%$ of no board seats. The model predicts having a board seat better than to predict not having one.

\subsection{What is the likelihood that Philippine listed companies will have a woman Board of Director?}

A total of 248 companies were analysed, information sourced from the Philippine Stock Exchange electronic monitoring system, the Securities and Exchange Commission, and EMIS database. Table 3 shows the variables used as predictors in a multivariate logistic model to determine their impact on the outcome that companies will have a female board of director. It should be noted that in the sample, 161 or $65 \%$ of the total number of companies, had female board of directors. This translates to an average of 1.5 female directors per company. On the overall, the majority of companies $(70 \%)$ had above average market capitalization, were largely considered large businesses based on employee size and only 7 percent had foreign shareholders. Industry categories were slightly skewed towards manufacturing/energy/power firms (36\%) and property/leisure/IT/logistics/distribution (32\%).

Table 3: Measure of Independent Variables Used - Secondary or Firm Level Data

\begin{tabular}{|c|c|c|c|}
\hline Variable & Description & Codes & $\begin{array}{l}\text { Count or } \\
\text { Frequency } \\
\text { N=248 (\%) }\end{array}$ \\
\hline $\begin{array}{l}\text { Total number } \\
\text { of directors }\end{array}$ & Number of board of directors (mean $=9.6$ ) & Actual number & \\
\hline \multirow{2}{*}{$\begin{array}{l}\text { Market } \\
\text { capitalization }\end{array}$} & \multirow{2}{*}{$\begin{array}{l}\text { Refers to the market value of a } \\
\text { company's outstanding share (average } \\
=\text { Php140,176) }\end{array}$} & $1=$ Above average & $173(70 \%)$ \\
\hline & & $0=$ Below average $^{a}$ & $70(30 \%)$ \\
\hline \multirow{3}{*}{ Company size } & \multirow{3}{*}{$\begin{array}{l}\text { Measured by number of employees. } \\
\text { Small businesses, 10-99; medium } \\
\text { enterprise has 100-199; and } 200 \text { beyond } \\
\text { considered large. }\end{array}$} & $1=$ Small business & $67(27 \%)$ \\
\hline & & $2=$ Medium enterprise & $18(7 \%)$ \\
\hline & & $3=$ Large business $^{\mathrm{a}}$ & $163(66 \%)$ \\
\hline \multirow{2}{*}{$\begin{array}{l}\text { Foreign } \\
\text { ownership }\end{array}$} & \multirow{2}{*}{$\begin{array}{l}\text { Owner in a company with nationality } \\
\text { listed }\end{array}$} & $\begin{array}{l}1=1 \text { or more foreign } \\
\text { owners }\end{array}$ & $16(7 \%)$ \\
\hline & & $0=$ No foreign owners ${ }^{\mathrm{a}}$ & $232(93 \%)$ \\
\hline \multirow{4}{*}{ Industry } & \multirow{4}{*}{ Sectoral categories of companies } & $1=$ Holding firms $^{\mathrm{a}}$ & $37(14 \%)$ \\
\hline & & $\begin{array}{l}2=\text { Manufacturing, Energy } \\
\text { or Power }\end{array}$ & $88(36 \%)$ \\
\hline & & $3=$ Financial & $30(12 \%)$ \\
\hline & & $\begin{array}{l}\text { 4= Communications/ } \\
\text { Media/Schools }\end{array}$ & $15(6 \%)$ \\
\hline
\end{tabular}




\begin{tabular}{|c|c|c|c|}
\hline Variable & Description & Codes & $\begin{array}{c}\text { Count or } \\
\text { Frequency } \\
\mathbf{N}=\mathbf{2 4 8}(\%)\end{array}$ \\
\hline & & $\begin{array}{l}5=\text { Property, Hotel \& } \\
\text { leisure, IT, Logistics or } \\
\text { Distribution }\end{array}$ & $78(32 \%)$ \\
\hline \multirow[t]{2}{*}{$\begin{array}{l}\text { Interaction } \\
\text { term } \\
\text { (Industry*Mar } \\
\text { ket } \\
\text { capitalization) }\end{array}$} & \multirow[t]{2}{*}{$\begin{array}{l}\text { interaction between a given industry and } \\
\text { market capitalization (above average) }\end{array}$} & $\begin{array}{l}\text { Specific industry (e.g. } \\
\text { financial) with above } \\
\text { average market } \\
\text { capitalization }\end{array}$ & $\begin{array}{l}\text { Industry } \\
1=17(7 \%) \\
2=26 \\
(10 \%) \\
3=10(4 \%) \\
4=5(2 \%) \\
5=17(7 \%)\end{array}$ \\
\hline & & $\begin{array}{l}\text { Companies with below } \\
\text { average market } \\
\text { capitalization }^{\mathrm{a}}\end{array}$ & $70(30 \%)$ \\
\hline
\end{tabular}

Table 4 presents the odds ratios from the firm-level multivariate regression model on the likelihood for companies to have a female board member. A good model fit was obtained, as based on the statistically significant chi-value across iterations and settling at the final model, chi value $\chi^{2}=$ 20.95 , highly significant at $0.001(\mathrm{p}<0.05)$. A non-significant Hosmer-Lemeshow goodness of fit $(\chi 2=5.37, \mathrm{df}=6, \mathrm{p}=0.496)$, is a desired outcome, signifying the close match of predicted to observed values. Nagelkerke Pseudo-R2 indicates that the final model accounts for a weak explanation of the variance in data (pseudo $\mathrm{R} 2=0.111$ ), declining from the highest at 0.14 at the first iteration of the model.

Table 4: Odds Ratio Results from Logistic Regression Using Secondary/Firm level Data

\begin{tabular}{|c|c|c|c|c|c|}
\hline Predictor variables & Model 1 & Model 2 & Model 3 & Model 4 & Model 5 \\
\hline & $\begin{array}{l}\text { OR } \\
(95 \% \mathrm{CI}) \\
\end{array}$ & $\begin{array}{l}\text { OR } \\
(95 \% \mathrm{CI})\end{array}$ & $\begin{array}{l}\text { OR } \\
(95 \% \mathrm{CI})\end{array}$ & $\begin{array}{l}\text { OR } \\
(95 \% \mathrm{CI})\end{array}$ & $\begin{array}{l}\text { OR } \\
(95 \% \mathrm{CI}) \\
\end{array}$ \\
\hline Market capitalization & $\begin{array}{l}0.9 \\
(0.2-4.0)\end{array}$ & & & & \\
\hline \multicolumn{6}{|l|}{ Industry } \\
\hline Energy/Power/Mftg & $\begin{array}{l}0.6 \\
(0.2-2.0)\end{array}$ & $\begin{array}{l}0.6 \\
(0.3-1.6)\end{array}$ & & & \\
\hline Financial & $\begin{array}{l}1.2 \\
(0.4-8.9)\end{array}$ & $\begin{array}{l}1.9 \\
(0.4-8.1)\end{array}$ & & & \\
\hline $\begin{array}{l}\text { Community/Social \& } \\
\text { personal services }\end{array}$ & $\begin{array}{l}0.9 \\
(0.2-4.7)\end{array}$ & $\begin{array}{l}0.9 \\
(0.2-4.3)\end{array}$ & & & \\
\hline Property/IT/Logistics/ & 0.9 & 0.9 & & & \\
\hline Distribution & $(0.3-2.8)$ & $(0.4-2.4)$ & & & \\
\hline \multicolumn{6}{|l|}{ Company size } \\
\hline Small Business & 1.0 & 1.0 & 1.0 & & \\
\hline
\end{tabular}




\begin{tabular}{|c|c|c|c|c|c|}
\hline Predictor variables & Model 1 & Model 2 & Model 3 & Model 4 & Model 5 \\
\hline & $(0.5-2.0)$ & $(0.5-2.0)$ & $(0.5-2.0)$ & & \\
\hline Medium Enterprise & $\begin{array}{l}2.2 \\
(0.6-7.6)\end{array}$ & $\begin{array}{l}2.2 \\
(0.6-7.7)\end{array}$ & $\begin{array}{l}2.3 \\
(0.7-7.9)\end{array}$ & & \\
\hline Foreign ownership & $\begin{array}{l}0.3 \\
(0.1-1.6)\end{array}$ & $0.3(0.1-1.6)$ & $0.3(0.1-1.5)$ & $0.3(0.1-1.6)$ & \\
\hline \multicolumn{6}{|l|}{$\begin{array}{l}\text { Interaction term } \\
\text { (Industry*Market } \\
\text { capitalization) }\end{array}$} \\
\hline Energy/Power/Mftg & $\begin{array}{l}1.2 \\
(0.2-6.9)\end{array}$ & $\begin{array}{l}1.1 \\
(0.4-2.8)\end{array}$ & $\begin{array}{l}0.8 \\
(0.3-1.9)\end{array}$ & $\begin{array}{l}0.8 \\
(0.3-1.8)\end{array}$ & $\begin{array}{l}0.8 \\
(0.3-1.8)\end{array}$ \\
\hline Financial & $\begin{array}{l}0.2 \\
(0.0-2.5)\end{array}$ & $\begin{array}{l}0.2 \\
(0.0-1.3)\end{array}$ & $\begin{array}{l}0.4 \\
(0.1-1.8)\end{array}$ & $\begin{array}{l}0.4 \\
(0.1-1.7)\end{array}$ & $\begin{array}{l}0.4 \\
(0.1-1.6)\end{array}$ \\
\hline $\begin{array}{l}\text { Communications/Med } \\
\text { ia/Schools }\end{array}$ & $\begin{array}{l}0.1 \\
(0.0-1.2)\end{array}$ & $\begin{array}{l}0.0 \\
(0.0-0.8)^{*}\end{array}$ & $\begin{array}{l}0.0 \\
(0.0-0.6)^{* *}\end{array}$ & $\begin{array}{l}0.1 \\
(0.0-0.7)^{* *}\end{array}$ & $\begin{array}{l}0.1 \\
(0.0-1.0)^{*}\end{array}$ \\
\hline $\begin{array}{l}\text { Property/IT/Logistics/ } \\
\text { Distribution }\end{array}$ & $\begin{array}{l}0.3 \\
(0.0-2.1)\end{array}$ & $\begin{array}{l}0.3 \\
(0.1-0.9)^{*}\end{array}$ & $\begin{array}{l}0.3 \\
(0.1-0.9)^{*}\end{array}$ & $\begin{array}{l}0.3 \\
(0.1-0.9)^{*}\end{array}$ & $\begin{array}{l}0.3 \\
(0.1-0.9)^{*}\end{array}$ \\
\hline \multicolumn{6}{|l|}{ Model Fit Statistics } \\
\hline Chi-square & $26.730 * *$ & $28.199 * *$ & $25.202 * * *$ & $23.287 * * *$ & $20.951 * * *$ \\
\hline Hosmer-Lemeshow & 6.788 & 5.335 & 4.916 & 3.576 & 5.379 \\
\hline Nagelkerke $R^{2}$ & 0.148 & 0.147 & 0.133 & 0.123 & 0.111 \\
\hline
\end{tabular}

Note: The dependent variable was likelihood of having at least 1 female board members with No female board member $(=0)$ as reference category and at least 1 female board member as target category $(=1)$

$* \mathrm{p}<0.05$

$* * \mathrm{p}<0.001$

Source of data: Institute of Corporate Directors' compilation from PSE Edge website, SEC and other 2016 information in EMIS

The significant predictor variables in the model, holding other variables constant, were board size or total number of directors, and particular industry types interacting with market capitalization significant at $\mathrm{p}<0.05$. The odds ratio for board size was 1.3 , with narrow confidence interval. Holding other variables constant, as the size of boards increase by a unit, the odds of having a woman on board increased 1.3 times. Compared to holding firms, communications/media/school services, and property/IT/ logistics/distribution industries interacted with market capitalization and surfaced as significant predictor variables, although at below 1 odd ratios of 0.1 and 0.3 respectively, significant at $\mathrm{p}=0.46$ and $\mathrm{p}=0.27(\mathrm{p}<0.05)$, respectively. Controlling for other variables, having a woman on the boards were less likely for industries with low market capitalization, compared to holding or highly diversified companies.

The model's predicting capacity of successful outcome of having women on boards was moderately high at 66.5 , with correct prediction rates of $95 \%$ for the successful outcome of having women on boards, and $15.7 \%$ prediction rates for predicting those without women on boards. 


\subsection{What is the Likelihood that Philippine Listed Companies Will Have A Woman Board of Director?}

This section presents an alternative method to assess for some individual characteristics as a way of examining the robustness of earlier analysis. The research explored other quantitative measures to detect for patterns in the responses. Text mining is the discovery of previously unknown information through automatic extraction of information from written resources or unstructured data. Text mining seeks to extract patterns from natural language text. It is a variation of a research field called data mining, which deals with large structured data usually coming from databases (Hearst, 1999).

A total of 89 responses were analysed to find out if there were significant correlations among the responses. Pre-processing techniques such as tokenization, text transformation, stop word removal, n-gram generation, were applied to the responses on the following survey variables.

1. Sex

2. $\quad$ Age Group

3. Number of Board Membership

4. School where Bachelor's Degree was acquired

5. Location of School where Bachelor's Degree was acquired

6. School where Advanced Degree was acquired

7. Location of School where Advanced Degree was acquired

8. Acquired Professional License

9. Job Title

10. Industry

\subsubsection{Correlation Analysis}

Correlation analysis was used to find out which of the responses among the ten questions would statistically show interdependence. Samples without Age Group Data and without Board Membership were filtered from the data set. Table 5 shows the correlation matrix generated for this analysis.

Table 5: Correlation Matrix of Responses to Questions 1 thru 10

\begin{tabular}{lcccccccccc}
\hline \hline Attributes & Sex & $\begin{array}{c}\text { Age } \\
\text { Group }\end{array}$ & $\begin{array}{c}\text { No } \\
\text { Board } \\
\text { Mem }\end{array}$ & Industry & $\begin{array}{c}\text { BS } \\
\text { School }\end{array}$ & $\begin{array}{c}\text { BS } \\
\text { School } \\
\text { Loc }\end{array}$ & $\begin{array}{c}\text { Adv } \\
\text { School }\end{array}$ & $\begin{array}{c}\text { Adv } \\
\text { School } \\
\text { Loc }\end{array}$ & $\begin{array}{c}\text { Prof } \\
\text { Lic }\end{array}$ & $\begin{array}{c}\text { Job } \\
\text { Title }\end{array}$ \\
\hline Sex & 1 & 0.107 & 0.028 & 0.073 & 0.012 & -0.057 & 0.019 & -0.174 & -0.271 & 0.047 \\
Age Group & 0.017 & 1 & 0.185 & 0.040 & 0.108 & 0.072 & -0.041 & 0.182 & -0.071 & 0.045 \\
No Board & 0.028 & 0.185 & 1 & -0.119 & -0.229 & -0.228 & -0.147 & -0.046 & 0.038 & -0.161 \\
Mem & & & & & & & & & & \\
Industry & 0.073 & 0.040 & -0.119 & 1 & 0.392 & 0.045 & 0.760 & 0.224 & 0.287 & 0.767 \\
BS School & 0.012 & 0.108 & -0.229 & 0.392 & 1 & 0.144 & 0.612 & 0.066 & 0.400 & 0.606 \\
BS School Loc & -0.057 & 0.072 & -0.228 & 0.045 & 0.144 & 1 & 0.033 & 0.147 & 0.350 & -0.045 \\
Adv School & 0.019 & -0.041 & -0.147 & 0.760 & 0.612 & 0.033 & 1 & 0.177 & 0.378 & 0.927
\end{tabular}




\begin{tabular}{lcccccccccc}
\hline \hline \multicolumn{1}{c}{ Attributes } & Sex & $\begin{array}{c}\text { Age } \\
\text { Group }\end{array}$ & $\begin{array}{c}\text { No } \\
\text { Board } \\
\text { Mem }\end{array}$ & Industry & $\begin{array}{c}\text { BS } \\
\text { School }\end{array}$ & $\begin{array}{c}\text { BS } \\
\text { School } \\
\text { Loc }\end{array}$ & $\begin{array}{c}\text { Adv } \\
\text { School }\end{array}$ & $\begin{array}{c}\text { Adv } \\
\text { School } \\
\text { Loc }\end{array}$ & $\begin{array}{c}\text { Prof } \\
\text { Lic }\end{array}$ & $\begin{array}{c}\text { Job } \\
\text { Title }\end{array}$ \\
\hline Adv School & -0.174 & 0.182 & -0.046 & 0.224 & 0.066 & 0.147 & 0.177 & 1 & 0.275 & 0.266 \\
Loc & & & & & & & & & & \\
Prof Lic & -0.271 & -0.071 & 0.038 & 0.287 & 0.400 & 0.350 & 0.378 & 0.275 & 1 & 0.374 \\
Job Title & 0.047 & 0.045 & -0.161 & 0.767 & 0.606 & -0.045 & 0.927 & 0.266 & 0.374 & 1 \\
\hline \hline
\end{tabular}

The findings indicate that in certain industries, respondents who have earned advanced degrees were most likely to attend the same school. Therefore, the school network may have played a significant role in the industry and position or job titles held by the respondents. Having advanced degrees correlated strongly with industry, bachelor's degrees and job titles. Those with advanced degrees are likely to have gone to same school and ended up with similar C-suite job titles like Chief Executive Officer, Chief Financial Officer, and the like.

\section{DISCUSSION}

The study explored the factors that can influence wider gender representation on boards from two angles: firstly, exploring the likelihood of having a board seat, from a sample of strong aspirants in a directors' talent pool; and secondly, determining the likelihood of a company having a female board of director, using public data submissions. Using the same individual data in the talent pool, we used text mining technique, by way of corroboration, on the variables that can shed further light on the issue. Results revealed that at the individual level sex does affect the odds of board selection, with females having .10 odds compared to males. There were no significant differences observed between sexes on their likelihood to get on corporate boards in terms of age and advanced degrees per se. A woman with advanced degree significantly had higher likelihood of being on boards, holding other factors constant, at 7 times odds, compared to males and other females.

The significance of these individual characteristics is supportive of human capital theory that puts importance to the accumulation of stocks of education, skills and experience in the expansion of production or national economic growth (Becker, 1964). Advanced degrees confer higher status to the holder and a perception of greater ability, according to status characteristics theory (Biernat \& Kobrynowicz, 1997 as cited in Terjesen, Couto, \& Francisco, 2015). Burgess and Tharenou (2002), in their review on common characteristics of female board members, found that most females acquired board seats from C-level positions, have higher degrees and managerial experience; illustrative of women needing to have higher human and social capital for their positions. Our use of the text mining technique corroborated on the importance of advanced degrees and found strong correlation of advanced degrees with job titles and industry.

The correlation of job titles with advanced degrees makes a point for depth of academic credentials in a powerful or leadership position as an identifier for board qualities, increasing one's chances for board selection. Our data showed that nearly equal proportions of our sample of men (76\%) and women $(77 \%)$ had advanced degrees. That women directors are more likely to have an advanced degree than their male counterparts in U.S. for Fortune 1000 companies was also reported in Hillman, Cannella, and Harris, (2002). However, Singh (2008 as cited in Terjesen, Couto, \& Francisco, 2015) found that men are likely to hold $\mathrm{CEO} / \mathrm{COO} / \mathrm{MD}$ roles and that women were less 
likely to be executive directors. As experience at the highest levels or having powerful job titles increase the likelihood of getting into boards, the pathway to board membership is narrowed. Supporting more women to build or grow companies can be one avenue for advocacy and policy support.

The significance of industry type vis-à-vis other industries, point to industries having a nonconstant effect on the odds of the respondents getting on company boards, controlling for other factors in the models. The significance of the interaction of industry with market capitalization showed that having a woman on the boards were less likely for these industries with low market capitalization, compared to holding or highly diversified companies. This implies that the size of companies does matter, that is, larger companies are likely to have more depth in terms of gender diversity than smaller ones. A similar finding is reported in studies cited in Hillman, Shropshire, and Cannella (2007).

One board level data informed our analysis at the firm level; the size of boards increased the likelihood of having women on corporate boards. The larger the boards, the greater the number of women directors (Terjesen et al., 2009). With the likelihood of having at least a woman on the board at the odds of 1.3 for every point increase in the number of directors; thus, to double the number of women from the current sample mean of 1.5 per company, the number of directors must increase by 3 . Having a solo woman representation in boards may serve as mere tokenism and thereby limit women representation to solely being a female. Critical mass theory (Erkut, Kramer, \& Konrad, 2008 as cited in Terjesen et al., 2009) shows how real change occurs with three or more women on boards, and normalizes women's presence as leaders and not just as women. There is no cap to the size of boards to Philippine companies and the current average size of boards in the sample is nine (9). The finding is supportive of resource dependency theories (RDT) to indicate the contributions brought on by women as critical resources (Hillman et al., 2009). Large boards were found to be associated with greater diversity in terms of expertise, experience and stakeholder representation, which further enhanced corporate legitimacy and reputation (Al-Bassam, Ntim, Opong, \& Downs, 2018; Terjesen et al., 2009). While board size per se may be more than a function of profitability or scope of operations, expanding the size of boards can 'widen the net' and enable more women to be on the boards of corporations.

The key challenge to the research was the time and availability of the individuals concerned, in particular due to their roles. While we tapped into a talent pool of directors, time constraints and possibly discomfort with the online survey, may have affected our sampling. This may have provided us with a non-replicable profile and biased our estimates. Feedback to the group on the study's findings did not raise serious issues. Further research on the motivating factors and the current conditions of board participation is warranted, in industry settings; and with pipeline members holding current executive positions, tracking their pathway to board roles, if any.

In terms of implications for further research, industry level analysis is clearly lacking, as the reviews pointed out. More in-depth analyses can look into how the employment profile of these sectors, or having women in key executive positions, match the composition of their boards. Securing board seats can be a matter of being in industries that have a larger female employment base and thus greater women representation on their boards. Reviews have cited the lack of theorybased research on industry (Terjesen \& Singh, 2008). It would be of interest to do industry case studies to determine specific conditions in different industries that predispose or prevent more 
women to be on boards. Examining the way government selects the boards of corporation can be a starting point, as per our data, government had the least women representation and can be a 'low hanging fruit' for policy changes.

Though few factors or independent variables can explain the success of being on boards and for women to get on corporate boards, good model fit over-all and moderate to weak explanatory strength can be viewed as the information gaps in terms of increasing women representation in corporate boards. The female presence on boards is not large enough at present time to prove or disprove the business case for gender diversity, if the case needs to be shown. Institutional factors (following the work of Grosvold, 2011; Grosvold et al., 2016) have been barely alluded to, with potential directions showing the interplay of culture-regulation-industry-government as drivers of gender diversity in the boardrooms. Is board representation by women sensitive to the level of development of industries or the country in general? Are women valued as support generalists (e.g. MBAs, lawyers) when the environment is highly uncertain in terms of changes in political administration and regulatory frameworks? Will the new emerging industries in information technology (e.g. business process outsourcing and sharing economy) augur well for female representation on boards? The emerging or developing nature of firms as they engage in the market more widely, if not globally, may contribute to weaker or less delineated and articulated gender differences.

Philippine studies regarding the topic have limited documentation, except for work on indices and comparative rankings with countries. Due to limited documented contextual knowledge on key drivers and data, along with the limitations of the commission (time and varied perceptions), a methodology flexible enough was warranted. Logistic regression is relatively freed from making assumptions on the data and is accessible in terms of commercial availability of statistical packages. It is largely limited though in terms of outcome expression which has to be dichotomous. Doing so may have weakened its sensitivity as a result of data transformation or compression to nominal values.

Studying corporate boards is fraught as respondents have time constraints. Text mining allowed us further exploration as responses were taken for what they were and had no need for transformation. Given text mining's existential link to big data, more sample points would have added more iteration.

The findings can now generate, for the Philippines and similarly situated settings, further hypotheses to confirm or support the application of extant theoretical frameworks, which have been widely studied in western and/or international comparative contexts, possibly due to data availability. This exploration on women on the boardrooms of Philippine corporations confirmed some patterns which can be worth pursuing for further research and policy directions.

\section{ACKNOWLEDGEMENT}

The study, on which this article is based, was funded by the Institute of Corporate Directors, Philippines, and their donors and sponsors, in partnership with the Gov. Jose B. Fernandez, Jr. Ethics Center of the Ateneo Graduate School of Business. Earlier versions of the report were presented in public fora in Makati City and Sydney. A colleague further reviewed our work. The 
sponsors and reviewers, particularly comments received from the anonymous referee of this journal, are gratefully acknowledged. They are absolved of any errors of commission or omission this report may contain and those rest solely with the authors.

\section{REFERENCES}

Abdullah, S. N., Ismail, K. N. I. K., \& Nachum, L. (2016). Does having women on boards create value? The impact of societal perceptions and corporate governance in emerging markets: Women on Boards. Strategic Management Journal, 37(3), 466-476. https://doi.org/10.1002/smj.2352

Adams, R. B., \& Ferreira, D. (2009). Women in the boardroom and their impact on governance and performance. Journal of Financial Economics, 94(2), 291-309. https://doi.org/10.1016/j.jfineco.2008.10.007

Ahern, K. R., \& Dittmar, A. K. (2012). The changing of the boards: The impact on firm valuation of mandated female board representation. The Quarterly Journal of Economics, 127(1), 137-197. https://doi.org/10.1093/qje/qjir049

Al-Bassam, W. M., Ntim, C. G., Opong, K. K., \& Downs, Y. (2018). Corporate boards and ownership structure as antecedents of corporate governance disclosure in Saudi Arabian publicly listed corporations. Business \& Society, 57(2), 335-377. https://doi.org/10.1177/0007650315610611

Becker, G. S. (1964). Human Capital: A Theoretical and Empirical Analysis, with Special Reference to Education. Social Science Research Network. https://papers.ssrn.com/abstract=1496221

Biernat, M., \& Kobrynowicz, D. (1997). Gender- and race-based standards of competence: Lower minimum standards but higher ability standards for devalued groups. Journal of Personality and Social Psychology, 72(3), 544-557.

Bulaong Jr., O., \& del Rosario-Rondilla, A. (2018). Understanding Board Seat Membership of Women in Philippines Companies: Qualitative explorations [Unpublished manuscript, Ateneo Graduate School of Business, Institute of Corporate Directors].

Burgess, Z., \& Tharenou, P. (2002). Women Board Directors: Characteristics of the Few. Journal of Business Ethics, 37(1), 39-49.

Cabrera-Fernández, A. I., Martínez-Jiménez, R., \& Hernández-Ortiz, M. J. (2016). Women's participation on boards of directors: A review of the literature. International Journal of Gender and Entrepreneurship, 8(1), 69-89. https://doi.org/10.1108/IJGE-02-2015-0008

Deloitte Global Center for Corporate Governance. (2017). Women in the boardroom: A global perspective-5th edition. Retrieved from https://www2.deloitte.com/global/en/pages/ risk/articles/women-in-the-boardroom5th-edition.html

Erkut, S., Kramer, V. W., \& Konrad, A. (2008). Critical mass: Does the number of women on a corporate board make a difference? Women on Corporate Boards of Directors: International Research and Practice, 350-366.

Galbreath, J. (2018). Is board gender diversity linked to financial performance? The mediating mechanism of CSR. Business \& Society, 57(5), 863-889. https://doi.org/10.1177/0007650316647967

Grant Thornton. (2016). Women in business: Turning promise into practice-Grant Thornton International Business Report 2016. Grant Thornton International Ltd. 
Grosvold, J. (2011). Where are all the women? Institutional context and the prevalence of women on the corporate board of directors. Business \& Society, 50(3), 531-555. https://doi.org/10.1177/0007650311408791

Grosvold, J., Rayton, B., \& Brammer, S. (2016). Women on corporate boards: A comparative institutional analysis. Business \& Society, 55(8), 1157-1196. https://doi.org/10.1177/0007650315613980

Hearst, M. A. (1999). Untangling Text Data Mining. Proceedings of the 37th Annual Meeting of the Association for Computational Linguistics on Computational Linguistics, 3-10. https://doi.org/10.3115/1034678.1034679

Hillman, A. J., Cannella, A. A., \& Harris, I. C. (2002). Women and racial minorities in the boardroom: How do directors differ? Journal of Management, 28(6), 747-763. https://doi.org/10.1177/014920630202800603

Hillman, A. J., Withers, M. C., \& Collins, B. J. (2009). Resource dependence Theory: A review. Journal of Management, 35(6), 1404-1427. https://doi.org/10.1177/0149206309343469

Hillman, A., Shropshire, C., \& Cannella, A. A. (2007). Organizational predictors of women on corporate boards. Academy of Management Journal, 50(4), 941-952.

Kang, L. S., \& Payal. (2012). Women on corporate boards: A literature review. Indian Journal of Corporate Governance, 5(1), 33-49.

Kolev, K., Hughes-Morgan, M., \& Rehbein, K. (2019). The role of female directors in the boardroom: Examining their impact on competitive dynamics. Business \& Society, 000765031984747. https://doi.org/10.1177/0007650319847477

Mckinsey Global Institute. (2018). The power of parity: Advancing women's equality in Asia Pacific. Mckinsey \& Company.

Meyers, L. S., Gamst, G. C., \& Guarino, A. J. (2016). Applied Multivariate Research: Design and Interpretation (Third edition). SAGE Publications, Inc.

Osborne, J. W. (2015). Best Practices in Logistic Regression. SAGE Publications, Ltd. https://doi.org/10.4135/9781483399041

Pett, M. A. (2016). Nonparametric Statistics for Health Care Research: Statistics for Small Samples and Unusual Distributions (Second edition). SAGE Publications, Inc.

Pfeffer, J. (1972). Merger as a Response to organizational interdependence. Administrative Science Quarterly, 17(3), 382-394. JSTOR. https://doi.org/10.2307/2392151

Pfeffer, J., \& Salancik, G. R. (1978). The External Control of Organizations: A Resource Dependence Perspective (1 edition). Stanford Business Books.

Singh, V. (2008). Contrasting Positions of Women Directors in Jordan and Tunisia. In Women on Corporate Boards of Directors: International Perspectives and Challenges. Edward Elgar Publishing. https://www.elgaronline.com/view/9781847204806.00019.xml

Terjesen, S., Couto, E., \& Francisco, P. M. (2015). Does the presence of independent and female directors impact firm performance? A multi-country study of board diversity. Journal of Management and Governance.

Terjesen, S., Sealy, R., \& Singh, V. (2009). Women directors on corporate boards: A review and research agenda. Corporate Governance: An International Review, 17(3), 320-337. https://doi.org/10.1111/j.1467-8683.2009.00742.x

Terjesen, S., \& Singh, V. (2008). Female presence on corporate boards: A multi-country study of environmental context. Journal of Business Ethics, 83(1), 55-63. https://doi.org/10.1007/s10551-007-9656-1 
Unite, A. A., Sullivan, M. J., \& Shi, A. A. (2016). Women on Top: Diversity in Gender and Education Profiles of Top Management and Board of Directors of Philippine Publicly Traded Firms. Presented at the DLSU Research Congress 2016, 6.

Unite, A., Sullivan, M., \& Shi, A. (2016). Gender diversity in boards and performance of Philippine publicly traded firms: Do women matter? Angelo King Institute. http://www.pes.org.ph/files/Gender-Diversity-in-Boards-and-Performance-ofPhilippine-Publicly-Traded-Firms-Do-Women-Matter-Unite-et-al.pdf

Wagana, D. M., \& Nzulwa, J. D. (2016). Corporate governance, board gender diversity and corporate performance: A critical review of literature. European Scientific Journal, ESJ, 12(7), 221. https://doi.org/10.19044/esj.2016.v12n7p221

World Economic Forum. (2017). The global gender gap report: 2017. World Economic Forum. 